\title{
Reversible Immobilization of Chelating Affinity Surfactants on Reversed Phase Adsorbents for Protein and Peptide Separations under Metal Affinity Chromatography
}

\author{
Omar González-Ortega1,2, Roberto Guzmán ${ }^{1}$ \\ ${ }^{1}$ Chemical and Environmental Engineering Department, The University of Arizona, Tucson, USA \\ ${ }^{2}$ Bioprocess Engineering Department, Autonomous University of San Luis Potosí, San Luis Potosí, México \\ Email: guzmanr@u.arizona.edu
}

Received 4 August 2014; revised 19 September 2014; accepted 4 October 2014

Copyright (C) 2014 by authors and Scientific Research Publishing Inc.

This work is licensed under the Creative Commons Attribution International License (CC BY).

http://creativecommons.org/licenses/by/4.0/

(c) (i) Open Access

\begin{abstract}
Alkyl-bound silica was modified using chelating surfactants and the resulting adsorbent was used in immobilized metal affinity chromatography of proteins and peptides. Brij-76, a non-ionic amphiphilic surfactant with an alkyl moiety and an ethylene oxide chain, was reversible adsorbed to alkyl silica $\left(C_{18}\right)$. The hydroxyl group at the end of the ethylene oxide chain was chemically modified previously with an iminodiacetate functionality as chelating agent of transitional metal ions. $\mathrm{Cu}(\mathrm{II})$ was studied as immobilized ion for the adsorption of peptides and proteins. Three chromatographic supports were prepared having different $\mathrm{Cu}$ (II) capacities. For a low $\mathrm{Cu}$ (II) capacity case, the generated adsorbent behaved as a controlled access media preventing the adsorption of large molecular weight proteins, such as BSA, while small peptides, such as Angiotensin III, or amino acids could be retained. For a medium and high $\mathrm{Cu}$ (II) capacity, the synthesized adsorbent no longer behaved as a controlling access media and all molecules in this study, either large or small, were retained by the immobilized ion. Nonetheless, most of the BSA was strongly retained by the system and a pH change did not remove any of the adsorbed BSA while the small molecules were removed by the same $\mathrm{pH}$ change.
\end{abstract}

\section{Keywords}

IMAC, Brij, Chelating Surfactant, Restricted Access Media, Alkyl-Bound Silica 


\section{Introduction}

Alkyl silica, a common adsorbent for reversed phase chromatography of biological macromolecules [1], has been previously modified with surfactant molecules that adsorb hydrophobically forming hemi-micelles or bilayered structures as depicted in Figure 1 [2]. Several applications of similar modified adsorbents have emerged such as a generation of mixed mode adsorbents with hydrophobic and ion exchange properties [3]-[6], the fractionation of proteins by size exclusion using hydrophobic silica coated with non-ionic surfactants [7], the use of modified surfactants with affinity ligands, ion exchange groups or dyes at the end of the polyethylene glycol residue for protein purifications [8]-[11], the analysis of drugs using an alkyl-bound silica saturated with surfactants (Tween or Brij) [12], and the use of a polyoxyethylene-type non-ionic surfactant as a media for hydrophobic interaction chromatography [13].

During the creation of alkyl silica saturated with a surfactant that inhibits the interaction of a protein with alkyl residues, a surfactant containing a polyethylene glycol residue is necessary. Polyethylene glycol (PEG), either covalently grafted or hydrophobically adsorbed, has shown to prevent protein adsorption onto surfaces [12] [14]. Despite the PEG rejection properties, surfactants modified at the end of the PEG residue with an adsorption site are able to retain proteins during chromatographic procedures as previously described.

The recovery of proteins by immobilized metal affinity chromatography (IMAC) is widely known after the work of Porath et al. [15]. IMAC is primarily based on the interaction between histidine residues on the surface of a protein with immobilized metal ions present on a stationary phase through a coordination process. This coordination process is reversible and thus, proteins can be selectively purified after metal ion recognition by imidazole or $\mathrm{pH}$ gradients. Iminodiacetic acid as chelating agent and $\mathrm{Cu}(\mathrm{II})$ and $\mathrm{Ni}(\mathrm{II})$ as immobilized ions are by far the most employed for protein purification [16].

Chelating surfactants have been used to immobilize proteins on chromatographic beads. Ho et al. [17] in their approach they coated polystyrene beads with a Pluronic surfactant modified with a chelating agent loaded with

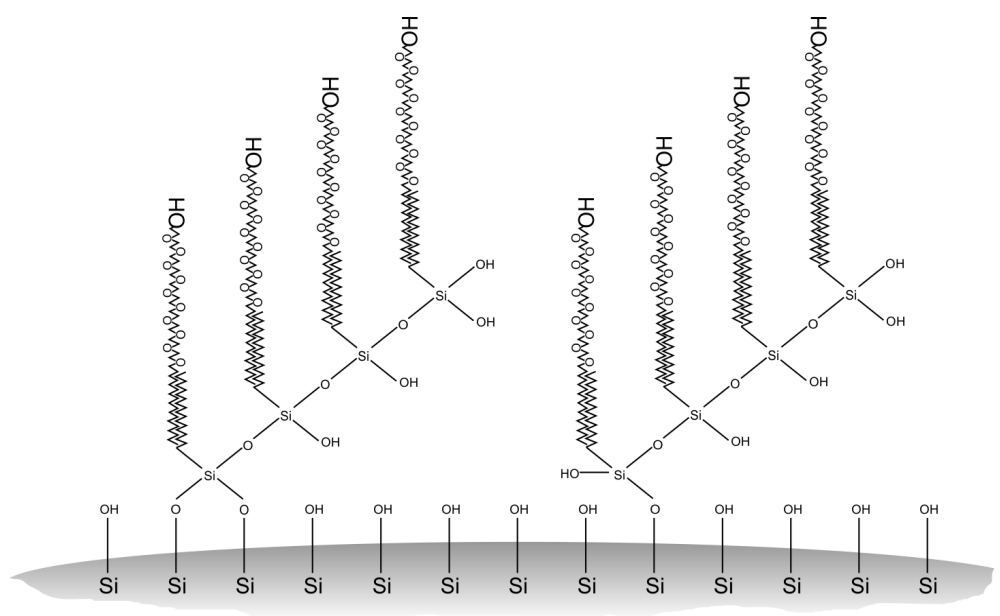

(a)

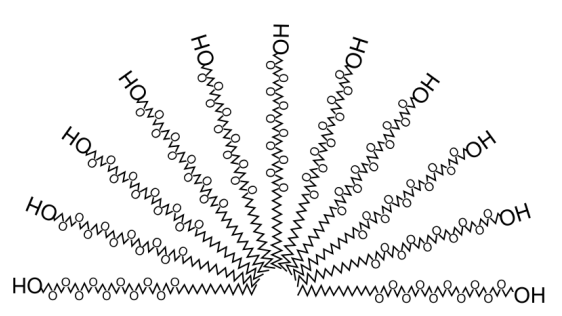

Alkyl silica

(b)

Figure 1. (a) Bi-layer and (b) Hemi-micelle structures formed by interaction of alcohol ethoxylates and alkyl-silica. 
a transitional metal ion and the resulting adsorbent was used for the immobilization of luciferase on the polystyrene beads.

Here we describe the synthesis of a chelate-derivatized surfactant using Brij derivatives and iminodiacetic acid (IDA) to form surfactant-IDA complexes and the reversible adsorption of these surfactant-chelates to octadecyl-bonded silica. Octadecyl-bound silica beads were coated with the surfactant-IDA derivatives and after loading with $\mathrm{Cu}(\mathrm{II})$ at different densities, used to study protein adsorption by IMAC interactions.

\section{Experimental}

\subsection{Chemicals}

Vydac silica $\mathrm{C}_{18}$ (218 TP) was purchased from Grace (USA). TP silica is a polymeric bonded phase (end-capped) with a pore size of $30 \mathrm{~nm}$. The surfactant Brij-76 was purchased from Sigma (USA). Thionyl chloride, ammonium hydroxide, absolute ethanol, bromoacetic acid, sodium hydroxide, hydrochloric acid, ethyl acetate, chloroform, sodium phosphate, sodium chloride, acetonitrile, bovine serum albumin (BSA), ribonuclease A (RNAse A), tryptophan (Trp) and histidine (His) were also acquired from Sigma (USA). The peptide Angiotensin III was obtained from Bachem (USA).

\subsection{Instrumentation}

Chromatographic analyses were performed using a Gilson HPLC system (USA) equipped with two isocratic pumps, a mixer, a manual injection valve (with a $0.5 \mathrm{~mL}$ sample loop), a UV-Vis detector, and a fraction collector. The system was controlled by the Unipoint software from Gilson. The chromatographic column was a glass column from Amersham Biosciences (USA) having an internal diameter of $0.5 \mathrm{~cm}$ and a length of $5 \mathrm{~cm}$. Synthesis of the chelating-surfactant derivative was performed using a Parr (USA) mini reactor with 4843 controller.

\subsection{Synthesis of Chelating-Surfactants}

The synthesis of chelating surfactants was performed by a three-step reaction scheme. In step 1, as an example, $10 \mathrm{~g}$ of Brij-76 were melted at $55^{\circ} \mathrm{C}$ under vacuum to remove water for $1 \mathrm{~h}$. Afterwards $5.2 \mathrm{~mL}$ of thionyl chloride were added under a nitrogen atmosphere and the temperature was increased to $65^{\circ} \mathrm{C}$. Chlorination continued for $6 \mathrm{~h}$. Then vacuum was applied to remove unreacted thionyl chloride for $2 \mathrm{~h}$. The product was dried overnight at $50^{\circ} \mathrm{C}$ in an oven. In step $2,40 \mathrm{~mL}$ of absolute ethanol were used to dissolve the modified surfactant and the solution was added to a reactor containing $400 \mathrm{~mL}$ of ammonia-saturated ethanol. The reactor was closed and the temperature raised to $100^{\circ} \mathrm{C}$, the reaction was let to proceed for $4 \mathrm{~h}$. The mixture was then cooled to room temperature (RT) and concentrated under vacuum. The aminated residue was finally dried overnight at $50^{\circ} \mathrm{C}$ in an oven. In step 3, the resulting solid was dissolved in $40 \mathrm{~mL}$ of hot ethanol $\left(70^{\circ} \mathrm{C}\right)$ and $2.05 \mathrm{~g}$ of bromoacetic acid (in $60 \mathrm{~mL}$ of ethanol with $2.16 \mathrm{~mL}$ of $10 \mathrm{M} \mathrm{NaOH}$ ) were added. The temperature was raised to $80^{\circ} \mathrm{C}$ and the reaction proceeded for $14 \mathrm{~h}$ controlling the $\mathrm{pH}$ in the range 8 - 9 adding $10 \mathrm{M} \mathrm{NaOH}$. The temperature was then lowered to RT and the solvent was eliminated under vacuum. The residue was suspended in $200 \mathrm{~mL}$ of water, acidifying the mixture to $\mathrm{pH} 1$ - 2 by adding concentrated hydrochloric acid. The resulting aqueous suspension was first extracted with ethyl acetate and then with chloroform. The organic solvent was evaporated and the residue dried in an oven at $50^{\circ} \mathrm{C}$ overnight. The involved reactions during the surfactant-chelating synthesis are depicted schematically in Figure 2. The TNBS test was used to determine the efficiency of steps 2 and 3.

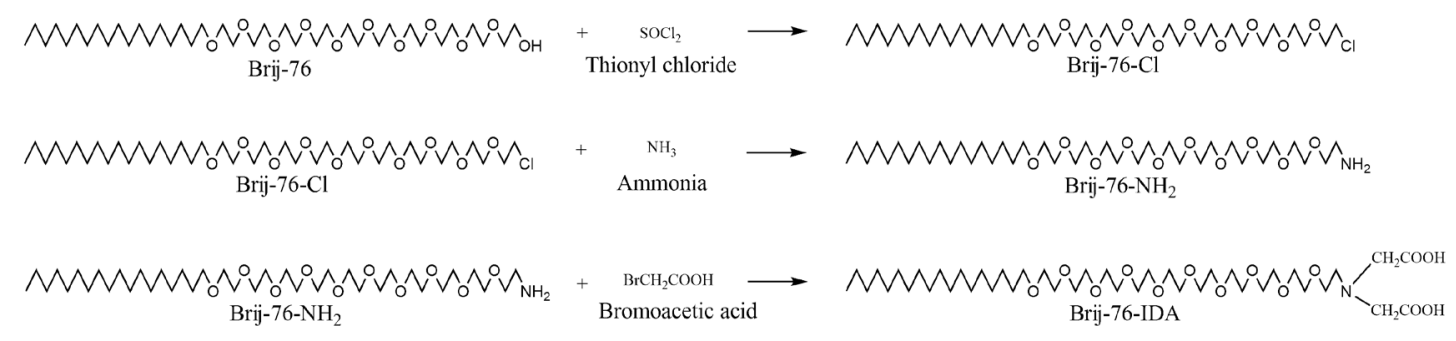

Figure 2. Surfactant modification to incorporate a chelating agent (iminodiacetic acid). 


\subsection{Surfactant Quantification}

Surfactant concentration in the native and chelating derivative was determined by the Bradford method [18] in which $0.2 \mathrm{~mL}$ of sample was mixed with $0.8 \mathrm{~mL}$ of protein reagent and the absorbance of the mixture was measured at $610 \mathrm{~nm}$.

\subsection{Adsorbent Preparation}

Octadecyl-bound silica was packed in a glass column $(0.5 \mathrm{~cm}$ ID) to a height of $2.7 \mathrm{~cm}$ using methanol at a flow rate of $2 \mathrm{~mL} / \mathrm{min}$. The column was then washed with DI water to remove the alcohol. The interaction and saturation of the silica matrix with the chelating surfactant was carried out by feeding the surfactant solution at a flow rate of $0.5 \mathrm{~mL} / \mathrm{min}$ until saturation. This was followed with a washing step with DI water to remove unbound surfactant. Afterwards, the column was equilibrated with a $10 \mathrm{mM} \mathrm{Cu(II)}$ solution. Unbound $\mathrm{Cu}(\mathrm{II})$ ions were also removed with DI water.

\subsection{Determination of Cu(II) Capacity on the Silica-Chelating-Surfactant Matrix}

The Cu(II) capacity in the prepared adsorbents was measured as follows. A glass column packed with surfactant modified adsorbent was fed with a $10 \mathrm{Mm} \mathrm{Cu(II)} \mathrm{solution} \mathrm{at} \mathrm{a} \mathrm{flow} \mathrm{rate} \mathrm{of} 0.5 \mathrm{~mL} / \mathrm{min}$ until saturation. Afterwards, DI water was fed to the column to remove unbound copper ions from the tubing and from the void volume in the column. The entire process was followed by measuring the absorbance of the eluate at $825 \mathrm{~nm}$. Once the breakthrough and washing curves were obtained, $\mathrm{Cu}(\mathrm{II})$ capacity was measured by the mass balance expressed in Equation (1).

$$
\mathrm{Cu}(\mathrm{II}) \text { capacity }(\mu \mathrm{mol} / \mathrm{mL})=\frac{F}{V}\left(c_{m 0} t_{f}-\int_{0}^{t_{w}} c_{m} d t\right)
$$

where $c_{m}$ is the measured $\mathrm{Cu}(\mathrm{II})$ concentration $(\mathrm{mM}), c_{m 0}$ is the fed $\mathrm{Cu}(\mathrm{II})$ concentration $(\mathrm{mM}), t$ is the time (min), $t_{f}$ is the $\mathrm{Cu}(\mathrm{II})$ solution feeding time (min), $t_{w}$ is the final time of experiment (min), $F$ is the flow rate $(\mathrm{mL} / \mathrm{min})$, and $V$ is the column volume $(\mathrm{mL})$.

\subsection{Surfactant Saturation Capacity of Octadecyl-Bound Silica}

The surfactant capacity of the reversed-phase adsorbent was measured by the same method used for $\mathrm{Cu}$ (II) capacity, with the quantification of surfactant concentration on the eluate by the Bradford method as previously described. A similar equation to Equation (1) was then used to estimate the amount of surfactant retained by the alkyl silica.

\subsection{Protein and Peptide Adsorption Studies}

Once the alkyl-bound silica was modified with the chelating surfactant and loaded with Cu(II) ions, the column was equilibrated with buffers $\mathrm{B}$ and $\mathrm{A}$ at a flow rate of $0.5 \mathrm{~mL} / \mathrm{min}$. Buffer A consisted of $20 \mathrm{mM} \mathrm{PO}, 500 \mathrm{mM}$ $\mathrm{NaCl}, \mathrm{pH} 7.0$ while buffer B was $100 \mathrm{mM} \mathrm{PO}_{4}, 500 \mathrm{mM} \mathrm{NaCl}, \mathrm{pH} 4.0$.

Once the system was equilibrated with buffer A (adsorption buffer), a $0.5 \mathrm{~mL}$ sample was injected. Absorbance of the eluate was followed at 220 or $280 \mathrm{~nm}$. After a washing step with the same buffer A, buffer B (desorption buffer) was fed to remove specifically retained molecules.

\section{Results and Discussion}

\subsection{Synthesis of the Chelating Surfactant}

Brij-76 was successfully modified to bear an iminodiacetic moiety. First the efficiency of Brij-76 amination was quantified using the TNBS test. This test revealed that approximately 60\% of the original Brij-76 molecule was aminated. The same TNBS was used to determine the absence of amino groups in the Brij-76 molecule after carboxymethylation. The chemical structures of the native and the chelating surfactants are shown in Figure 3 . 


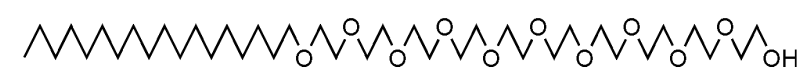

Brij-76

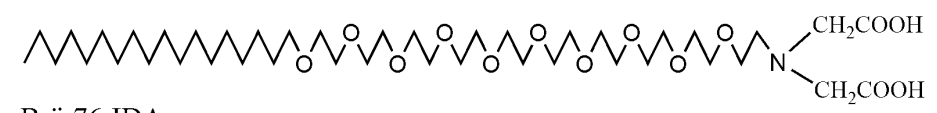

Brij-76-IDA

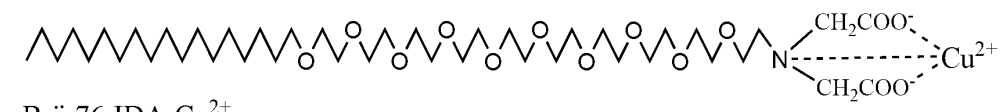

Brij-76-IDA-Cu${ }^{2+}$

Figure 3. Chemical structures of native and modified Brij-76 having immobilized $\mathrm{Cu}(\mathrm{II})$ ions.

\subsection{Surfactant and Cu(II) Capacity of Modified Adsorbents}

The surfactant capacities on the reversed-phase columns for native and modified Brij-76 were determined. For the modified surfactants, the $\mathrm{Cu}(\mathrm{II})$ capacity was also determined and the results are shown in Table 1 . The surfactant capacity on the reversed-phase matrix for the native molecule was similar to the capacities obtained by Sing et al. [12] for Brij-76 on $\mathrm{C}_{18}$ Davisil $(109 \mathrm{mg} / \mathrm{mL})$ and on $\mathrm{C}_{18}$ Ultrabase (104 mg/mL). The adsorption of these amphiphilic surfactants on hydrophobic silica, in general, changes the polarity of the adsorbent since the polyethylene glycol moieties are exposed to the aqueous solvent. The surfactant adsorption from an aqueous solution above the critical micelle concentration on an alkyl residue is schematically depicted in Figure 4. Since the test $\mathrm{C}_{18}$ silica has a pore size of $30 \mathrm{~nm}$, while dimensions of the Brij surfactants lay in the range 2 - $5 \mathrm{~nm}$ [19], the surfactant molecules are expected to enter the pores of the adsorbent and adsorb at the alkyl moieties of the silica reducing the surface area and pore volume while preserving the pore shape [20] [21]. Once the surfactants are adsorbed on the alkyl silica surface they can form hemispherical structures called hemi-micelles as has been suggested by Rosen [22].

The measured $\mathrm{Cu}(\mathrm{II})$ capacities for chelating surfactants were comparable with $\mathrm{Cu}(\mathrm{II})$ capacities from commercial IMAC systems reported in the literature [23]. Two of the surfactant-IDA derivatives Brij-76-IDA ${ }^{1}$ (low $\mathrm{Cu}(\mathrm{II})$ capacity) and Brij-76-IDA² (medium $\mathrm{Cu}(\mathrm{II})$ capacity) were obtained from the ethyl acetate liquid-liquid extraction procedure while a third derivative Brij-76-IDA ${ }^{3}$ (high $\mathrm{Cu}(\mathrm{II})$ capacity) was obtained from the chloroform extraction procedure. Since ethyl acetate is slightly less polar than chloroform, it seems to have preference for the unmodified surfactant which is expected to be less polar than the IDA-modified surfactant.

The HLB value for the original Brij-76 is reported in Table 1, this value implies that this surfactant has slightly favored hydrophilic properties. The introduction of the iminodiacetic acid functionality in the Brij-76 molecule is expected to increase these hydrophilic properties. This situation could explain the slightly lower surfactant capacity between Brij-76-IDA ${ }^{3}$ and Brij-76.

\subsection{Protein and Peptide Adsorption Studies: Plain $\mathrm{C}_{18}$ Silica}

Figure 5 presents the chromatograms from pulse analyses of BSA $(2 \mathrm{mg} / \mathrm{mL})$, Angiotensin III $(0.05 \mathrm{mg} / \mathrm{mL})$, $\operatorname{Trp}(0.04 \mathrm{mg} / \mathrm{mL})$, and His $(0.03 \mathrm{mg} / \mathrm{mL})$ dissolved in DI water with $0.1 \%$ TFA. The elution of the material adsorbed by the octadecyl groups attached to the silica matrix was achieved by feeding acetonitrile with $0.1 \%$ TFA. Both BSA and Angiotensin III samples were almost completely retained by the plain $\mathrm{C}_{18}$ silica while $30 \%$ of the His sample was not. Most of the Trp sample that was injected is only retarded on the plain $\mathrm{C}_{18}$ silica, only a small amount was retained hydrophobically and later recovered by the organic solvent. Trp and His where poorly retained by the plain $\mathrm{C}_{18}$ silica due to their hydrophilic behavior. The same results shown in Figure 5 were obtained (data not shown) after removing the surfactants using ACN recovering plain $\mathrm{C}_{18}$ silica.

\subsection{Protein and Peptide Adsorption Studies: Brij-76-IDA ${ }^{1}$ Derivative}

Once the $\mathrm{C}_{18}$ silica was saturated with Brij-76-IDA ${ }^{1}$ and equilibrated with the adsorption buffer, pulses of BSA $(1 \mathrm{mg} / \mathrm{mL})$, RNAse A (1 mg/mL), Angiotensin III (0.05 mg/mL), Trp $(0.05 \mathrm{mg} / \mathrm{mL})$ and His $(0.03 \mathrm{mg} / \mathrm{mL})$ were injected separately for analysis. The chromatograms are shown in Figure 6. In this case the system was not 


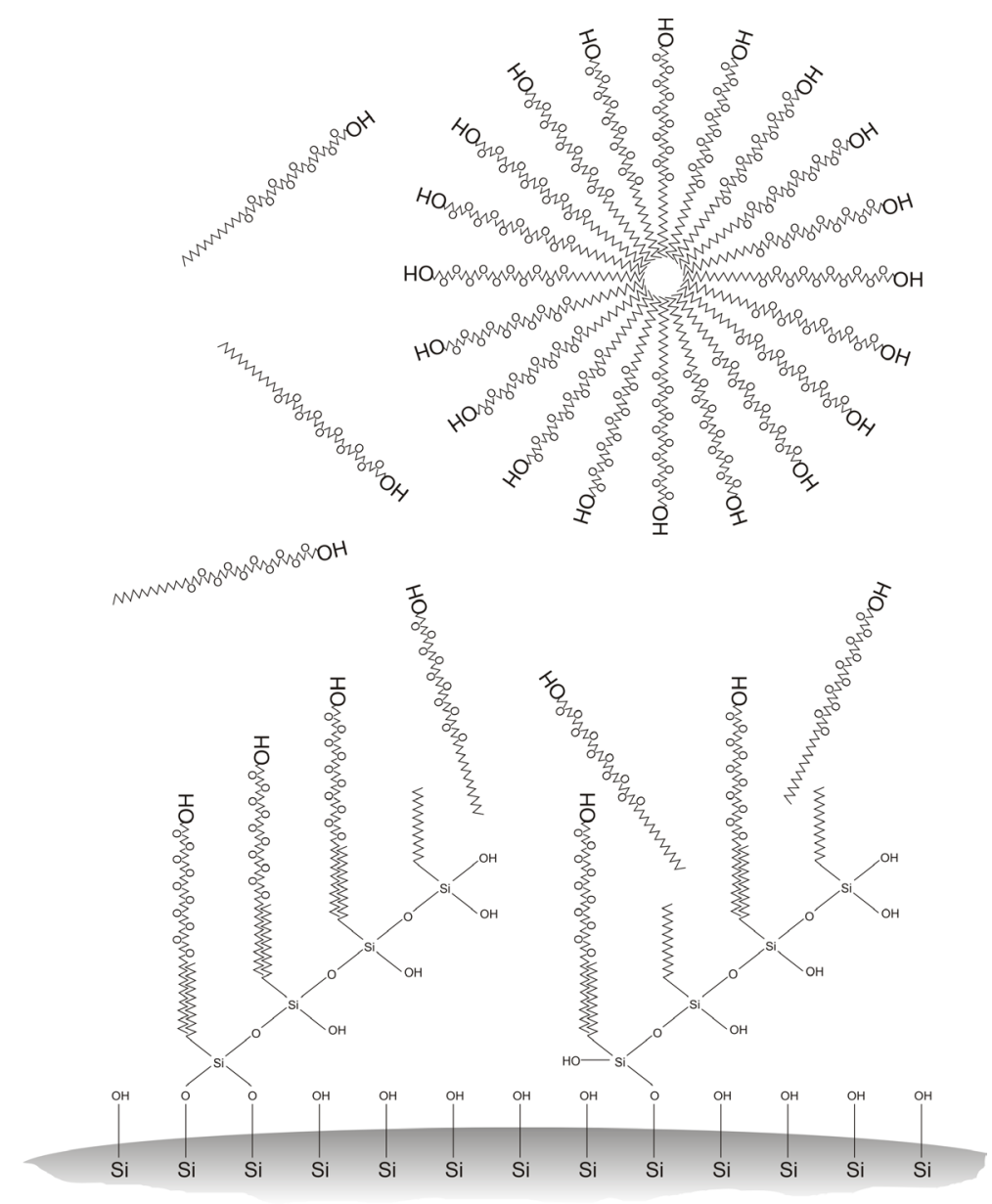

Figure 4. Adsorption of Brij-76 on $\mathrm{C}_{18}$ silica.
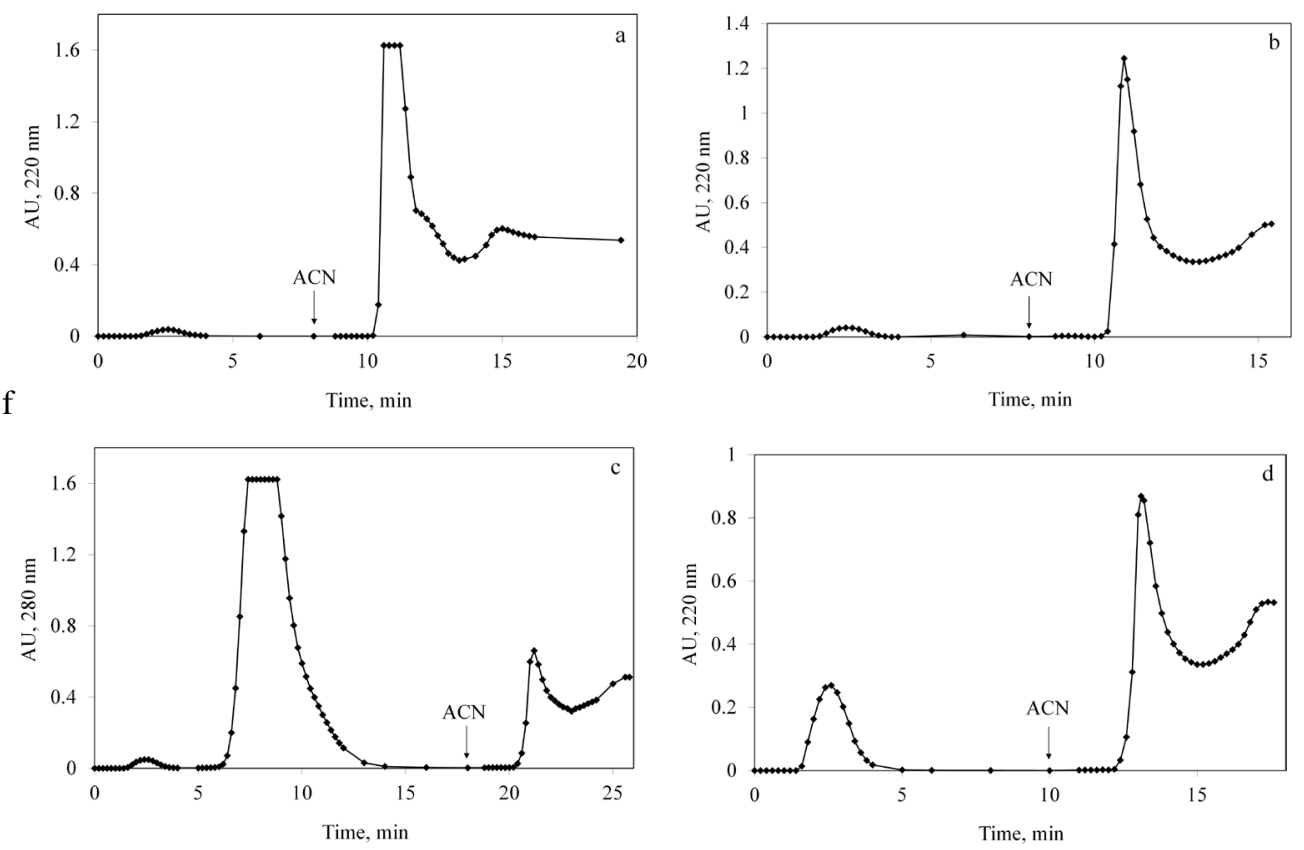

Figure 5. Pulse studies chromatograms on plain $\mathrm{C}_{18}$ silica. (a) BSA; (b) Angiotensin III; (c) Trp; (d) His. 

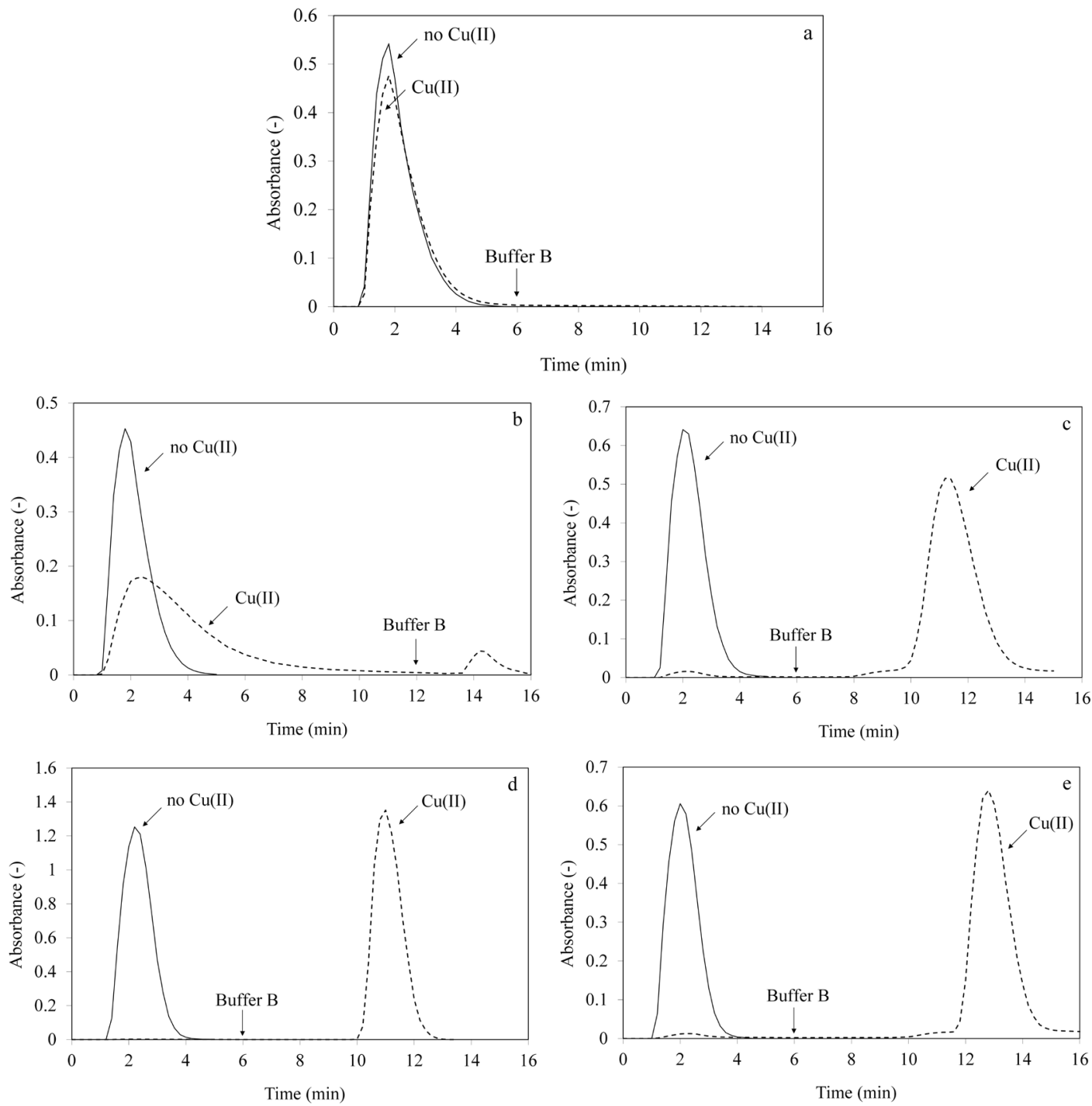

Figure 6. Pulse studies chromatograms on $\mathrm{C}_{18}$ silica covered with Brij-IDA ${ }^{1}$ with and without $\mathrm{Cu}(\mathrm{II})$ ions. (a) BSA; (b) RNAse A; (c) Angiotensin III; (d) Trp; (e) His.

Table 1. Cu(II) and surfactant capacities for studied adsorbents.

\begin{tabular}{ccccc}
\hline Surfactant & Surfactant capacity, $\mathrm{mg} / \mathrm{mL}$ & $\mathrm{Cu}(\mathrm{II})$ capacity, $\mu \mathrm{mol} / \mathrm{mL}$ & $\mathrm{CMC}, \mu \mathrm{M}$ & $\mathrm{HLB}$ \\
\hline Brij-76 & 117 & 0 & 3 & 12.7 \\
Brij-76-IDA $^{1}$ & 124 & 10 & - & - \\
Brij-76-IDA $^{2}$ & 105 & 27 & - & - \\
Brij-76-IDA $^{3}$ & 95 & 66 & - & - \\
\hline
\end{tabular}

loaded with $\mathrm{Cu}(\mathrm{II})$ ions and thus, none of the test molecules were retained. The proteins or peptides left the column with the void volume. The molecules were not retained by ion exchange processes either since the adsorption buffer had a high ionic strength to inhibit electrostatic interactions. These results corroborate that the adsorbent has changed polarity due to the presence of the ethylene oxide chain, changing from a hydrophobic to a hydrophilic adsorbent. Moreover, the test molecules are being excluded from the hydrophobic surface by the widely known rejecting properties of polyethylene glycol [24]. The alkyl silica $\left(\mathrm{C}_{18}\right)$ was not accessible even for 
small molecules such as His. A similar behavior was obtained by Chang [7] where glycyl-tyrosine was not retained hydrophobically by diphenyl silica covered with Tween.

Two theories have been considered towards the molecular description of the interaction between PEG and proteins for the creation of non-fouling surfaces. The first theory considers that the PEG layer induces a steric repulsion of proteins associated with an entropic repulsion originated from the compression of the PEG layer [25] [26]. The second theory considers that the affinity of water molecules towards oxygen atoms in the PEG chains is high enough to avoid protein interaction [24]. The PEG water affinity relies on the conformation of the polymers that offers two hydrogen bond acceptors in ideal distance for hydrogen bonding with water [27].

\subsection{Protein and Peptide Adsorption Studies: Brij-76-IDA1-Cu(II), Low Cu(II) Capacity}

In this case the Brij-76-IDA ${ }^{1}$-saturated $\mathrm{C}_{18}$ silica was equilibrated with $\mathrm{Cu}(\mathrm{II})$ ions and with desorption and adsorption buffers. The modified adsorbent was equilibrated with the desorption buffer to remove weakly bound $\mathrm{Cu}(\mathrm{II})$ ions. Pulses of BSA and RNAse A were tested and the resulting chromatograms are shown in Figure 6. Unexpectedly, BSA was almost completely unretained since none of the protein was recovered upon application of the desorption buffer (see Figure 6(a)). Only a small amount (7\% of the amount injected) of RNase A was recovered with the desorption buffer (see Figure 6(b)). BSA and RNAse A are known to have affinity towards immobilized Cu(II) ions by iminodiacetic acid [28] [29]. Since the chemical modification of the surfactant introduces an iminodiacetic acid functionality at the end of the ethylene oxide chain, $\mathrm{Cu}(\mathrm{II})$ ions should be exposed to the protein present in the aqueous buffer. Thus, these $\mathrm{Cu}(\mathrm{II})$ ions should be able to retain the test proteins.

The observed non-retention of proteins could be associated to several factors. First it is necessary to consider the structure of the adsorbent which is silica modified polymerically for the incorporation of the alkyl chains. Once the surfactant is adsorbed on these alkyl moieties, and with the fact that the number of surfactant molecules bearing an IDA functionality is less than the native surfactant, the probability that an IDA-modified surfactant is buried by the presence of native surfactant is high and thus, $\mathrm{Cu}(\mathrm{II})$ ions are not accessible for protein retention. Another possibility is the consideration of the hemi-micelle formation in which the IDA-modified surfactant is closer to the surface and it is being protected by the ethylene oxide chains of the native surfactants that complete the hemi-micelle. Finally, the reduction in pore size has to be considered since this effect will make difficult for the proteins to enter the adsorbent.

Another factor that could be considered is the expected distribution of molecular weight oligomers present with the surfactant Brij-76. This surfactant theoretically contains 10 ethylene oxide units but the reaction product will also contain, in large proportion, surfactant molecules with higher or lower ethylene oxide units according to a Poisson distribution [30]-[32]. Considering for example, a Poisson distribution with 10 ethylene oxide units, only $12.5 \%$ of the molecules will be present as Brij-76. Molecules with 9 ethylene oxide units will be likely present in the same percentage (12.5\%) while molecules with 11 units will represent $11.4 \%$. Thus, it is possible that if the surfactant molecules with 10 or less ethylene oxide units are being preferentially modified to bear an iminodiacetic acid moiety and if these modified surfactant molecules are closer to the surface and somehow protected by the longer unmodified surfactant molecules, the observed behavior could be explained.

By considering any of these possibilities, a small peptide or protein could be more easily retained since the native surfactant will only exert a minor influence on their adsorption. To test the latter concept, Angiotensin III, Trp, and His were injected to the system and the results are shown in Figure 6. All these molecules were retained by the immobilized $\mathrm{Cu}(\mathrm{II})$ ions and desorbed by a $\mathrm{pH}$ change necessary to disrupt the associated chelation. Angiotensin III, Trp and, His have been demonstrated to possess affinity towards immobilized Cu(II) ions on IDA [33].

According to the previous results, it was considered to determine if mixtures of large molecules with small molecules could be separated to corroborate a potential restricted access situation. Thus, mixtures of BSA (0.5 $\mathrm{mg} / \mathrm{mL})$ with Angiotensin III $(0.025 \mathrm{mg} / \mathrm{mL})$ or His $(0.015 \mathrm{mg} / \mathrm{mL})$ were injected to the system to determine the retention properties of the modified adsorbents. The results for these experiments are shown in Figure 7 where it is clear that only a small (almost negligible) amount of BSA is retained while the small molecules are completely retained and thus, they are being separated from the large molecular weight protein. The latter represents an extraordinary result since a restricted access chromatographic medium was created using common $\mathrm{C}_{18}$ silica as support. 

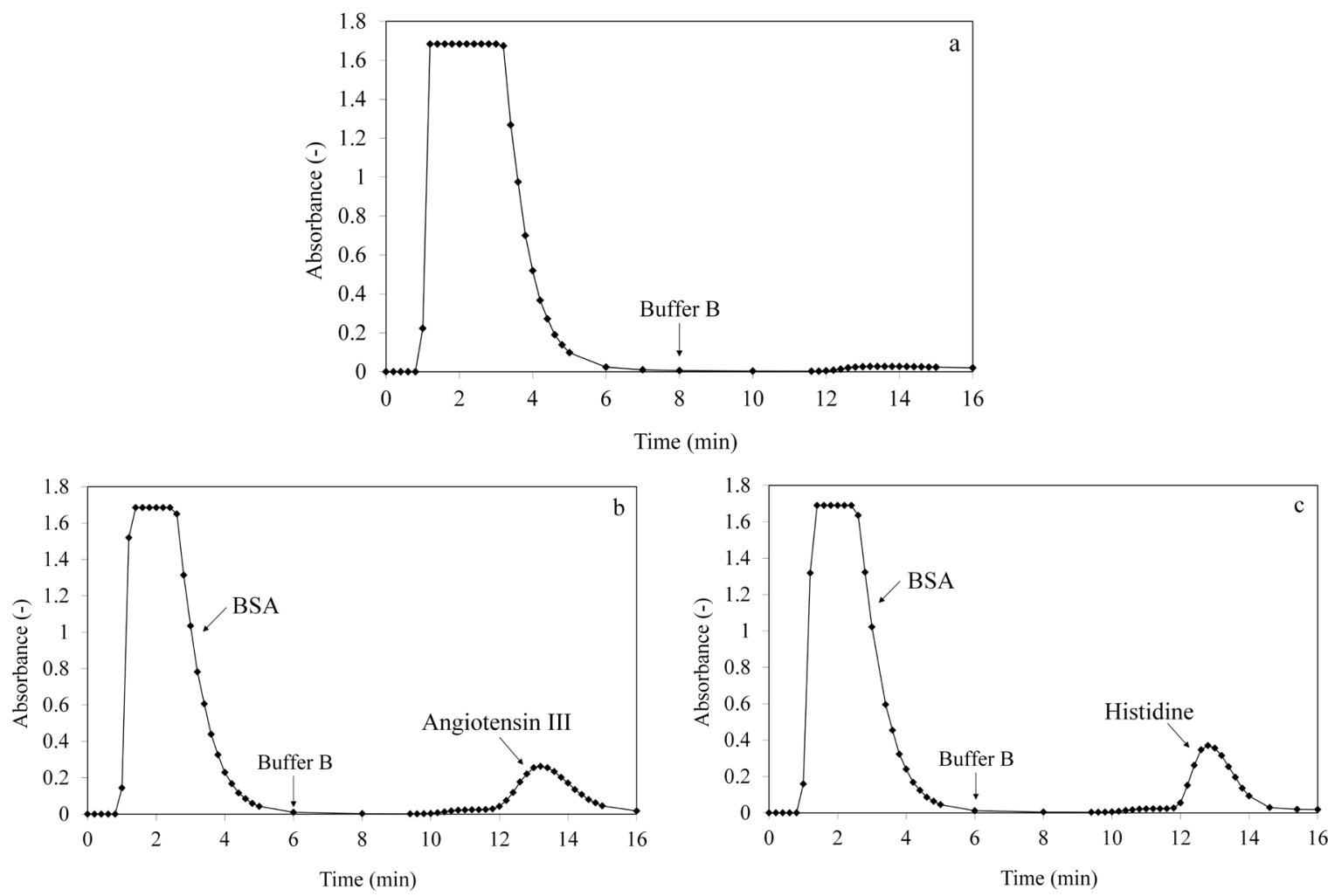

Figure 7. Pulse studies chromatograms on $\mathrm{C}_{18}$ silica covered with Brij-IDA ${ }^{1}-\mathrm{Cu}(\mathrm{II})$. (a) BSA; (b) BSA + Angiotensin III; (c) BSA + His.

\subsection{Protein and Peptide Adsorption Studies: Brij-76-IDA²-Cu(II), Medium Cu(II) Capacity}

Alkyl silica was saturated with Brij-76-IDA ${ }^{2}$ and after equilibration with the adsorption buffer pulses of BSA (1 $\mathrm{mg} / \mathrm{mL})$, RNAse A $(1 \mathrm{mg} / \mathrm{mL})$, Angiotensin III $(0.05 \mathrm{mg} / \mathrm{mL})$, Trp $(0.05 \mathrm{mg} / \mathrm{mL})$, and His $(0.03 \mathrm{mg} / \mathrm{mL})$ were injected and the chromatograms obtained were similar to the results presented with the alkyl silica saturated with Brij-76-IDA $^{1}$ (data not shown). As expected, none of these test molecules were retained by the system. Now the system was loaded with $\mathrm{Cu}(\mathrm{II})$ ions and pulses of the test molecules were performed. Desorption of adsorbed molecules was accomplished by a $\mathrm{pH}$ change. Despite the presence on an unretained peak for the injection of BSA (Figure 8), it represents only a small amount of the total protein injected (the absorbance of the eluate was followed at $220 \mathrm{~nm}$ ). The amount of BSA that was recovered from the $\mathrm{pH}$ change was negligible. From these results it is clear that the system is strongly retaining BSA most likely due to multipoint interactions between surface histidines and immobilized $\mathrm{Cu}(\mathrm{II})$ ions. It is also clear that this result is derived from the increase of $\mathrm{Cu}(\mathrm{II})$ capacity by the modified surfactant. A pulse of RNAse A was also performed and $63 \%$ of the total injected protein was retained and recovered by a pH change. The increase in $\mathrm{Cu}(\mathrm{II})$ capacity is clearly increasing the amount of RNAse A that is being retained (it increased from 7\% to 63\%). Pulses of Angiotensin III, Trp, and His were also performed and the three substances were retained by the $\mathrm{Cu}(\mathrm{II})$ ions and recovered with a $\mathrm{pH}$ change (Figure 8). An increase in $\mathrm{Cu}(\mathrm{II})$ capacity increased the probability of exposed $\mathrm{Cu}(\mathrm{II})$ for protein or peptide interaction and thus, the adsorption of BSA and RNAse A was now possible. The schematic preparation of the adsorbent for the retention of peptides or proteins with $\mathrm{Cu}(\mathrm{II})$ ions is depicted in Figure 9.

Also, mixtures of BSA with Angiotensin III or His were injected to determine if the small molecules continued to be recovered by a pH change while BSA remains adsorbed on the chromatographic system. Both the peptide and the amino acid were successfully separated from the large molecular weight protein (data not shown).

\subsection{Protein and Peptide Adsorption Studies: Brij-76-IDA3-Cu(II), High Cu(II) Capacity}

The chloroform fraction of the reaction mixture from the surfactant modification recovered a highly IDA-subs- 

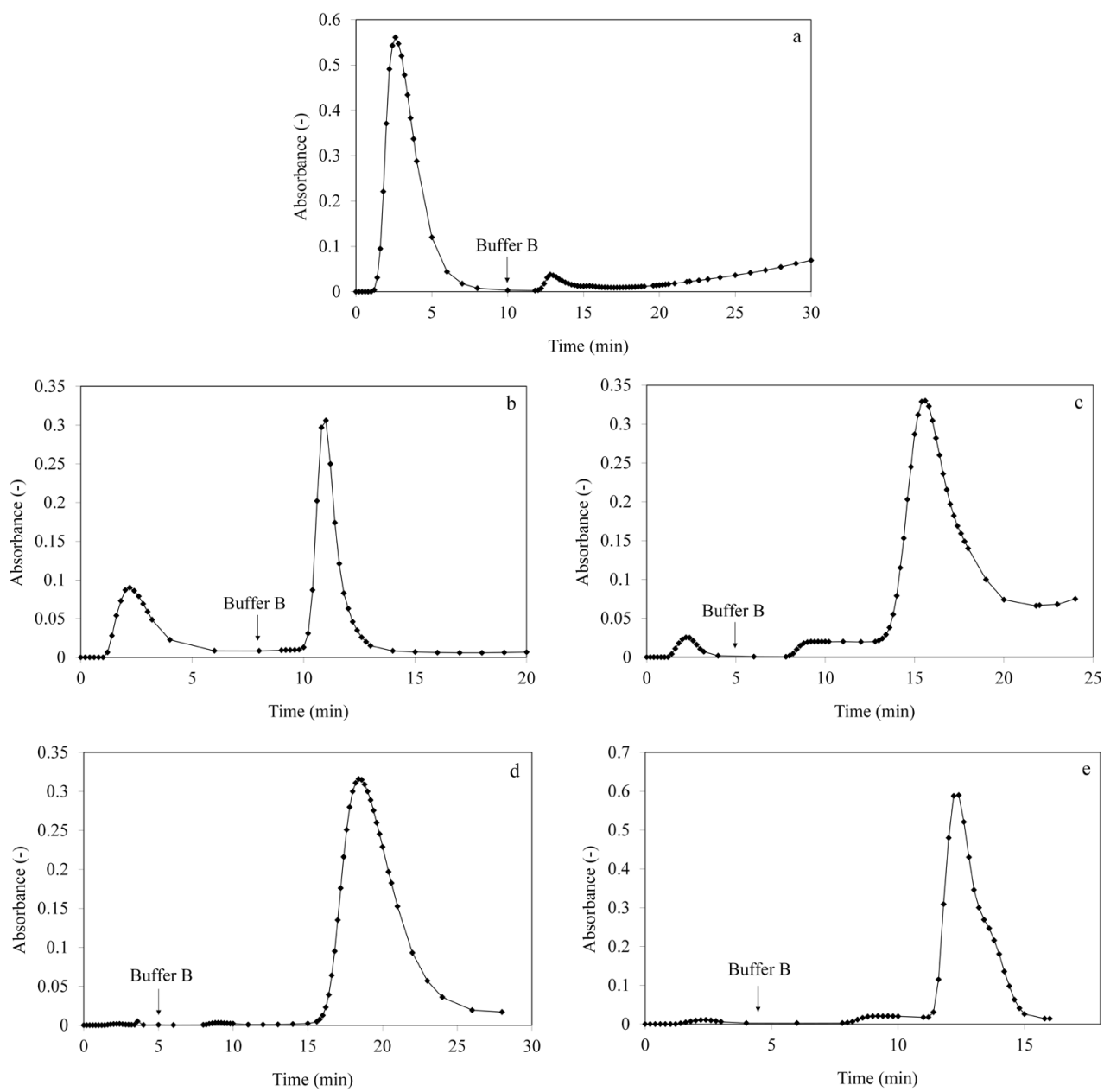

Figure 8. Pulse studies chromatograms on $\mathrm{C}_{18}$ silica covered with Brij-IDA ${ }^{2}-\mathrm{Cu}(\mathrm{II})$. (a) BSA; (b) RNAse A; (c) Angiotensin III; (d) Trp; (e) His.

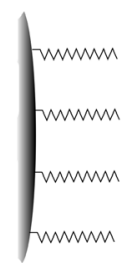

Alkyl silica

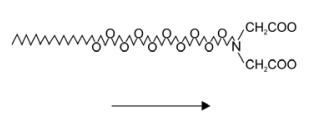

Brij-IDA

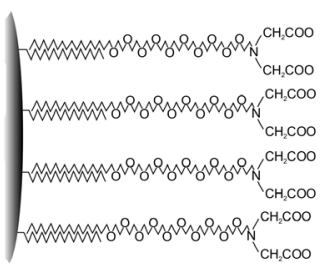

Alkyl silica-Brij-IDA

$$
\mathrm{Cu}^{2+}
$$

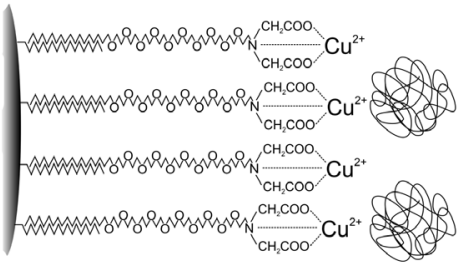

Alkyl silica-Brij-IDA-Cu ${ }^{2+}$-Protein

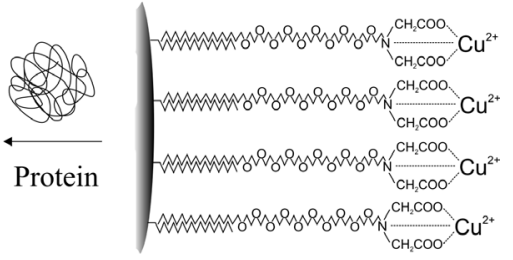

Alkyl silica-Brij-IDA-Cu ${ }^{2}$

Figure 9. Adsorption of proteins using immobilized $\mathrm{Cu}(\mathrm{II})$ ions supported by a chelating surfactant deposited over alkyl silica of Brij-76 on $\mathrm{C}_{18}$ silica. 
tituted Brij-76. A clean silica $\mathrm{C}_{18}$ was saturated with this surfactant and with a $\mathrm{Cu}(\mathrm{II})$ solution. After $\mathrm{Cu}(\mathrm{II})$ saturation, the original silica support changes from white to bright blue upon $\mathrm{Cu}(\mathrm{II})$ complexation. Pulse studies of BSA, RNAse A, Trp and His were performed on this system and the results are comparable to the system using the derivative Brij-76-IDA ${ }^{2}-\mathrm{Cu}(\mathrm{II})$. None of the proteins or the amino acids were retained with the system lacking $\mathrm{Cu}(\mathrm{II})$ ions (data not shown).

\section{Conclusions}

The surfactant Brij-76 was successfully modified to bear an iminodiacetate group at the end of the ethylene oxide chain. This modified surfactant was strongly adsorbed by its hydrophobic tail to silica $\mathrm{C}_{18}$. The leakage of surfactant from the silica $\mathrm{C}_{18}$ was minimal once the surfactant molecules were not present on the mobile phase. The adsorption of surfactant to the silica $\mathrm{C}_{18}$ clearly changed the polarity of the original support that originally presents adsorption of peptides or proteins by hydrophobic interactions. Once the surfactant was loaded with $\mathrm{Cu}(\mathrm{II})$ ions, the generated support served as a stationary phase for immobilized metal affinity chromatography and peptides and proteins were retained through interactions with the immobilized ions that were disrupted by a $\mathrm{pH}$ change allowing the recovery of some of the studied molecules.

Depending on the $\mathrm{Cu}(\mathrm{II})$ capacity of the attached surfactant (or in the number of surfactant molecules bearing an iminodiacetate group), the generated adsorbent could prevent the adsorption of large molecular weight proteins allowing the interaction of small peptides and amino acids with the immobilized ions creating thus, a restricted access media. Once the $\mathrm{Cu}(\mathrm{II})$ capacity was increased, all the studied molecules (having large and small molecular weights) were retained by the modified adsorbent. When BSA was retained by interaction with the immobilized ions, its recovery by a $\mathrm{pH}$ change was not possible revealing a high affinity likely derived from multipoint interactions between histidine residues from the surface of BSA and the $\mathrm{Cu}(\mathrm{II})$ ions.

\section{Acknowledgements}

O. G. O. acknowledges funding from PROMEP/103.5/12/3953 to complete the present work.

\section{References}

[1] Regnier, F.E. (1987) HPLC of Biological Macromolecules: The First Decade. Chromatographia, 24, $241-251$. http://dx.doi.org/10.1007/BF02688486

[2] Riordain, C.O., Barron, L., Nesterenko, E., Nesterenko, P.N. and Paull, B. (2006) Double Gradient Ion Chromatography Using Short Monolithic Columns Modified with a Long Chained Zwitterionic Carboxybetaine Surfactant. Journal of Chromatography A, 1109, 111-119. http://dx.doi.org/10.1016/j.chroma.2006.01.002

[3] Kelmers, A.D., Novelli, G.D. and Stulberg, M.P. (1965) Separation of Transfer Ribonucleic Acids by Reverse Phase Chromatography. Journal of Biological Chemistry, 240, 3979-3983.

[4] Weiss, J.F., Pearson, R.L. and Kelmers, A.D. (1968) Two Additional Reversed-Phase Chromatographic Systems for the Separation of Transfer Ribonucleic Acids and Their Application to the Preparation of Two Formylmethionine and a Valine Transfer Ribonucleic Acid from Escherichia coli B. Biochemistry, 7, 3479-3487. http://dx.doi.org/10.1021/bi00850a024

[5] Bischoff, R., Graeser, E. and McLaughlin, L.W. (1983) tRNA Separation by High-Performance Liquid Chromatography Using an Aggregate of Ods-Hypersil and Trioctylmethylammonium Chloride. Journal of Chromatography, 257, 305-315. http://dx.doi.org/10.1016/S0021-9673(01)88186-3

[6] Bischoff, R. and McLaughlin, L.W. (1985) Isolation of Specific tRNAs Using an Ionic-Hydrophobic Mixed-Mode Chromatographic Matrix. Analytical Biochemistry, 151, 526-533. http://dx.doi.org/10.1016/0003-2697(85)90215-5

[7] Chang, J.P. (1984) Effect of Surfactants on the Separation of Proteins by Reversed-Phase High-Performance Liquid Chromatography. I. Non-Ionic Surfactants (Tween). Journal of Chromatography, 317, 157-163. http://dx.doi.org/10.1016/S0021-9673(01)91655-3

[8] Torres, J.L., Guzman, R., Carbonell, R.G. and Kilpatrick, P.K. (1988) Affinity Surfactants as Reversibly Bound Ligands for High-Performance Affinity Chromatography. Analytical Biochemistry, 171, 411-418. http://dx.doi.org/10.1016/0003-2697(88)90507-6

[9] Guzman, R., Torres, J.L., Carbonell, R.G. and Kilpatrick, P.K. (1989) Water-Soluble Nonionic Surfactants for Affinity Bioseparations. Biotechnology and Bioengineering, 33, 1267-1276. http://dx.doi.org/10.1002/bit.260331007 
[10] Keller, D.E., Torres, J.L., Carbonell, R.G. and Kilpatrick, P.K. (1989) Reversible Conversion of Octadecyl-Bonded Silica to Ion-Exchange Surfaces for Protein Separations. Analytical Biochemistry, 176, 191-198. http://dx.doi.org/10.1016/0003-2697(89)90292-3

[11] Sing, Y.L.K., Algiman, E., Kroviarski, Y., Massot, C., Dhermy, D. and Bertrand, O. (1991) Modification of ReversedPhase Column with Dyed Surfactants. Preparation of Mechanically Resistant Efficient Immobilized Dyes for Protein Purification. Journal of Chromatography A, 558, 43-54. http://dx.doi.org/10.1016/0021-9673(91)80110-3

[12] Desilets, C.P., Rounds, M.A. and Regnier, F.E. (1191) Semipermeable-Surface Reversed-Phase Media for High-Performance Liquid Chromatography. Journal of Chromatography A, 544, 25-39. http://dx.doi.org/10.1016/S0021-9673(01)83976-5

[13] Sing, Y.L.K., Kroviarski, Y., Cochet, S., Dhermy, D. and Bertrand, O. (1992) High-Performance Hydrophobic Interaction Chromatography of Proteins on Reversed-Phase Supports Coated with Non-Ionic Surfactants of Polyoxyethylene Type Purification of a Fungal Aspartic Proteinase. Journal of Chromatography A, 598, 181-187. http://dx.doi.org/10.1016/0021-9673(92)85046-V

[14] Gombotz, W.R., Guanghui, W., Horbett, T.A. and Hoffman, A.S. (1991) Protein Adsorption to Poly(ethylene Oxide) Surfaces. Journal of Biomedical Materials Research, 25, 1547-1562. http://dx.doi.org/10.1002/jbm.820251211

[15] Porath, J., Carlsson, J., Olsson, I. and Belfrage, G. (1975) Metal Chelate Affinity Chromatography, a New Approach to Protein Fractionation. Nature, 258, 598-599. http://dx.doi.org/10.1038/258598a0

[16] Gutiérrez, R., del Valle, E.M.M. and Galán, M.A. (2007) Immobilized Metal-Ion Affinity Chromatography: Status and Trends. Separation and Purification Reviews, 36, 71-111. http://dx.doi.org/10.1080/15422110601166007

[17] Ho, C., Limberis, L., Caldwell, K.D. and Stewart, R.J. (1998) A Metal-Chelating Pluronic for Immobilization of Histidine-Tagged Proteins at Interfaces: Immobilization of Firefly Luciferase on Polystyrene Beads. Langmuir, 14, 38893894. http://dx.doi.org/10.1021/la980148k

[18] Bradford, M.M. (1976) A Rapid and Sensitive Method for the Quantitation of Microgram Quantities of Protein Utilizing the Principle of Protein-Dye Binding. Analytical Biochemistry, 72, 248-254. http://dx.doi.org/10.1016/0003-2697(76)90527-3

[19] Berthod, A. and Coque, C.G.A. (2000) Micellar Liquid Chromatography. Marcel Dekker, Inc., New York.

[20] Borgerding, M.F., Hinze, W.L., Stafford, L.D., Fulp, G.W. and Hamlin Jr., W.C. (1989) Investigations of Stationary Phase Modification by the Mobile Phase Surfactant in Micellar Liquid Chromatography. Analytical Chemistry, 61, 13531358. http://dx.doi.org/10.1021/ac00188a011

[21] Borgerding, M.F., Williams, R.L., Hinze, W.L. and Quina, F.H. (1989) New Perspectives in Micellar Liquid Chromatography. Journal of Liquid Chromatography, 12, 1367-1406. http://dx.doi.org/10.1080/01483918908049512

[22] Rosen, M.J. (2004) Surfactants and Interfacial Phenomena. John Wiley \& Sons, Inc., Hoboken. http://dx.doi.org/10.1002/0471670561

[23] Smith, M.C., Furman, T.C. and Pidgeon, C. (1987) Immobilized Iminodiacetic Acid Metal Peptide Complexes. Identification of Chelating Peptide Purification Handles for Recombinant Proteins. Inorganic Chemistry, 26, 1965-1969. http://dx.doi.org/10.1021/ic00259a030

[24] Morra, M. (2000) On the Molecular Basis of Fouling Resistance. Journal of Biomaterials Science, Polymer Edition, 11, 547-569. http://dx.doi.org/10.1163/156856200743869

[25] Szleifer, I. (1997) Protein Adsorption on Surfaces with Grafted Polymers: A Theoretical Approach. Biophysical Journal, 72, 595-612. http://dx.doi.org/10.1016/S0006-3495(97)78698-3

[26] Halperin, A. (1999) Polymer Brushes That Resist Adsorption of Model Proteins: Design Parameters. Langmuir, 15, 2525-2533. http://dx.doi.org/10.1021/la981356f

[27] Wattendorf, U. and Merkle, H.P. (2008) PEGylation as a Tool for the Biomedical Engineering of Surface Modified Microparticles. Journal of Pharmaceutical Sciences, 97, 4655-4669. http://dx.doi.org/10.1002/jps.21350

[28] Sulkowski, E. (1985) Purification of Proteins by IMAC. Trends in Biotechnology, 3, 1-7. http://dx.doi.org/10.1016/0167-7799(85)90068-X

[29] Sharma, S. and Agarwal, G.P. (2001) Interactions of Proteins with Immobilized Metal Ions: A Comparative Analysis Using Various Isotherm Models. Analytical Biochemistry, 288, 126-140. http://dx.doi.org/10.1006/abio.2000.4894

[30] Cross, J. (1987) Nonionic Surfactants. Chemical Analysis. Marcel Dekker, Inc., New York.

[31] Holmberg, K., Jonsson, B., Kronberg, B. and Lindman, B. (2003) Surfactants and Polymers in Aqueous Solutions. John Wiley \& Sons, West Sussex.

[32] Berthod, A., Tomer, S. and Dorsey, J.G. (2001) Polyoxyethylene Alkyl Ether Nonionic Surfactants: Physicochemical 
Properties and Use for Cholesterol Determination in Food. Talanta, 55, 69-83. http://dx.doi.org/10.1016/S0039-9140(01)00395-2

[33] Belew, M. and Porath, J. (1991) Immobilized Metal Ion Affinity Chromatography. Effect of Solute Structure, Ligand Density and Salt Concentration on the Retention of Peptides. Journal of Chromatography A, 516, 333-354. http://dx.doi.org/10.1016/S0021-9673(01)89275-X 
Scientific Research Publishing (SCIRP) is one of the largest Open Access journal publishers. It is currently publishing more than 200 open access, online, peer-reviewed journals covering a wide range of academic disciplines. SCIRP serves the worldwide academic communities and contributes to the progress and application of science with its publication.

Other selected journals from SCIRP are listed as below. Submit your manuscript to us via either submit@scirp.org or Online Submission Portal.
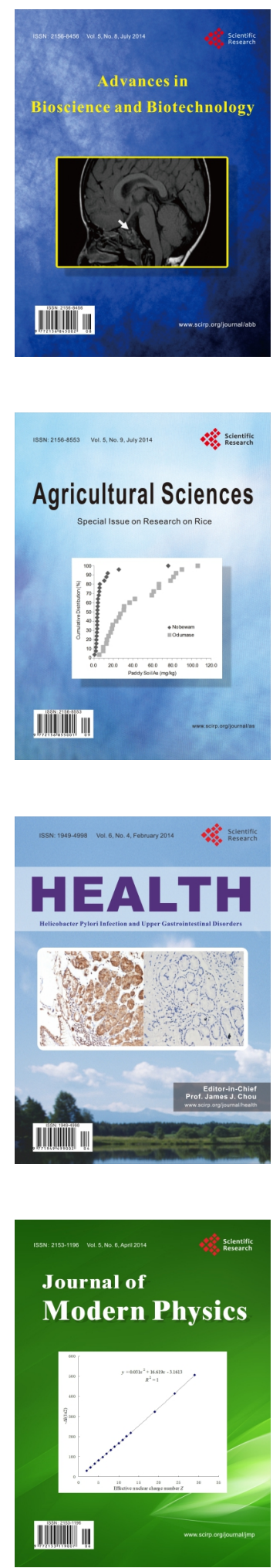
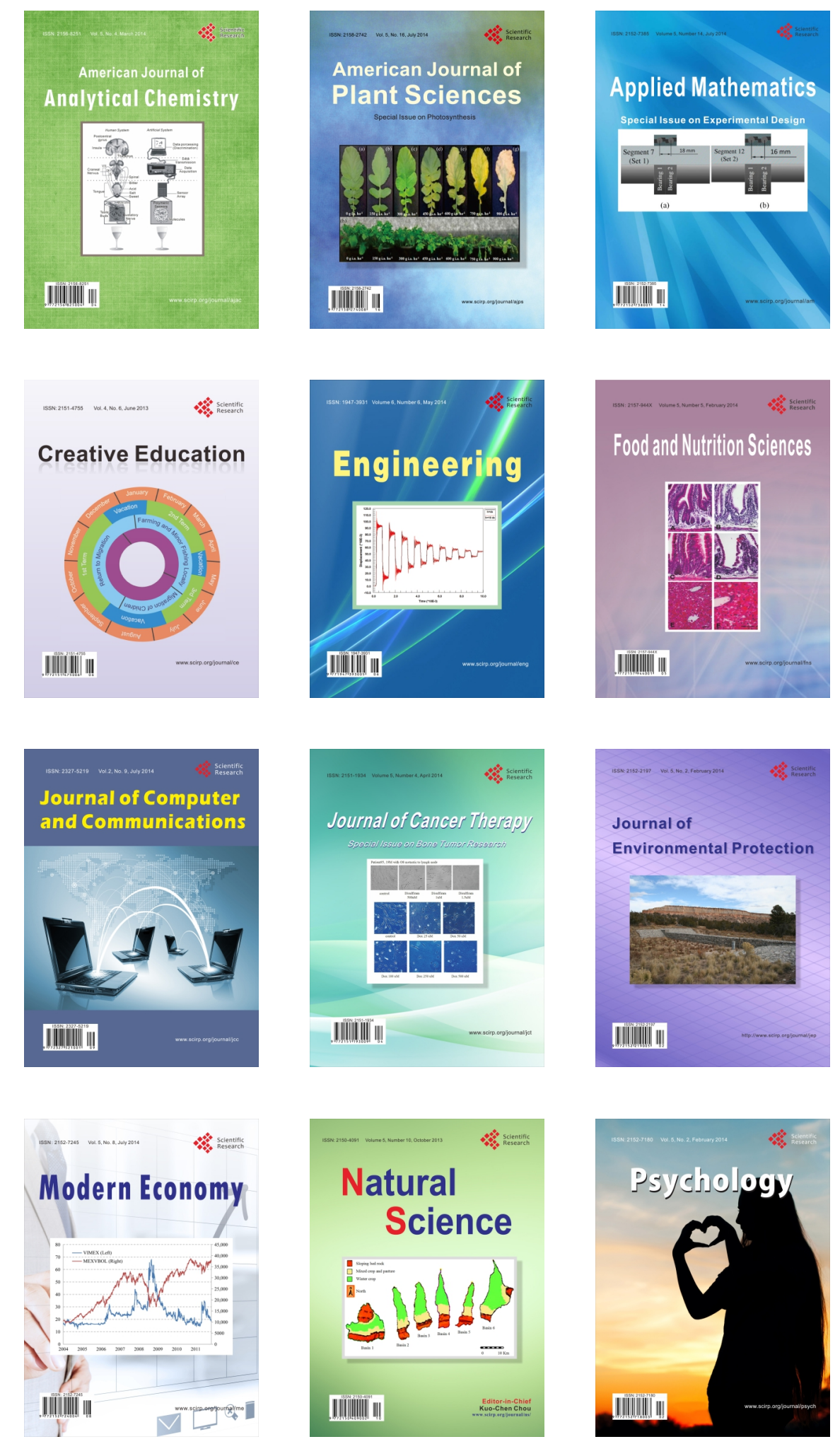